\title{
Children Asylum Seekers Face Challenges in the United States
}

\author{
Andrew Morton And Wendy A. Young
}

\section{Abstract}

This article outlines U.S. policy toward children asylum seekers. It highlights the gaps in U.S. detention and asylum policy which jeopardize the protection of children. It also discusses advances made in recent years, such as issuance of the U.S. "Guidelines for Children's Asylum Claims" which establish evidentiary, procedural, and legal standards for asylum adjudicators dealing with children's claims. Finally, it suggests reforms that are necessary to bring the United States into compliance with international law and to ensure that children are provided the refuge they deserve.

\section{Résumé}

Cet article donne les grandes lignes de la politique des ÉtatsUnis vis-à-vis des enfants demandeurs d'asile. Il met en exergue les lacunes de la politique américaine sur la détention et le droit d'asile, qui constituent une menace pour la protection des enfants. Par ailleurs, il discute aussi des progrès accomplis au cours des dernières années, comme par exemple, la délivrance par les États-Unis des "Directives concernant les demandes d'asile soumises par des enfants", document qui établit des normes procédurales, juridiques et en matière de preuves à l'intention des juges pour le droit d'asile appelés à statuer sur des demandes soumises par des enfants. Pour terminer, il propose des réformes nécessaires pour amener les États-Unis en conformité avec le droit international et pour assurer aux enfants la protection qu'ils méritent.

\section{Introduction}

arlos (a pseudonym) fled his home country of Honduras in search of refuge in the United States. Instead, he found jail. The United States Immigration and Naturalization Service ("INS" or the "Service") apprehended Carlos in south Texas, where he was first held in a children's detention center. The agency later transferred him to a juvenile jail in Liberty County, Texas, several hours away from the legal services program which was planning to represent Carlos after he expressed a fear of returning to Honduras. While he was locked up in the Liberty County jail, the INS instead persuaded Carlos to voluntarily depart the United States. Carlos was deported before an immigration judge had even considered his asylum claim.

Carlos is just one of thousands of unaccompanied children who arrive in the United States each year. In 2000 alone, the INS took nearly five thousand children into its custody, some as young as eighteen months old. Increasingly, among these numbers are children fleeing abuses such as forced military recruitment, female genital mutilation, forced marriages, child labour, and life as street children. Others may enter the United States because they have been abused, abandoned, or neglected by their parents or other caregivers, while some are seeking to reunify with family members who already have entered the United States. These children range in age from toddlers to teenagers, and an untold number are asylum-eligible. The INS does not track the types of relief from deportation sought by children in its custody, and therefore many children are not necessarily even aware that they may pursue refugee protection. ${ }^{1}$

U.S. policy toward children asylum seekers reflects a certain ambivalence. In recent years, the U.S. asylum system has progressed in terms of its recognition of the 
unique forms of persecution that children face around the world and the need to offer children a full opportunity to articulate their claims to asylum. On the other hand, the system falls short of providing the resources children need to assist them in their claims in the form of legal representation and the appointment of a guardian ad litem. Moreover, children asylum seekers are often detained for long periods of time, often in secure facilities, with little regard for their best interests.

\section{Detention of Unaccompanied Alien Children}

Unaccompanied alien children are those who arrive in the Unites States with no lawful immigration status and have no parent or legal guardian available to provide for their care and legal custody. Under United States immigration law, an alien child is defined as a foreign national under the age of eighteen, who either is the subject of a removal or exclusion proceeding under the Immigration and Nationality Act ("INA" or the "Act"), ${ }^{2}$ the central source of American immigration law, or has an asylum application pending before the INS. Although the INA does not actually define the term "unaccompanied minor," the Act does define the term "child" as an unmarried and unemancipated person under the age of twenty-one, ${ }^{3}$ although an alien child is treated as an adult for detention purposes upon attaining the age of eighteen.

Being unaccompanied by a parent or other legal guardian who is capable of providing for their care and custody, these children are subject to detention by the INS. Often these children are held for long periods of time-as long as a year or more-while their cases proceed through the immigration process. Under the existing system, the INS is responsible for an incongruous dual function-both the custodial care of these children, and the prosecutorial objective of arguing in favour of their removal proceedings. As a result, the INS faces an inherent conflict of interest-it is simultaneously a service provider and a law enforcement agency-which ultimately clogs the process with inefficiencies and threatens to undermine its ability to secure the best interests of the children taken into custody. Moreover, this conflict of interest is exacerbated by the fact that INS simply lacks the requisite child welfare training and expertise to care for children in an appropriate manner.

At the present time, the legal framework for custodial care and treatment of unaccompanied alien juveniles derives from a consent decree known as the Flores $v$. Reno settlement agreement ("Flores"). ${ }^{4}$ Originally filed as a class action lawsuit in the Federal court system, the case broadly challenged the civil rights treatment and constitutionality of practices, policies, and regulations regarding the detention and release of unaccompanied alien children taken into the custody of the INS. Following a prolonged legal battle that ascended to the United States Supreme Court before being remanded back to the
District Court of the Southern District of California, the class plaintiffs and the government reached a compromise in 1996. The resulting agreement broadly defines a litany of detention issues, including placement, transportation, monitoring and reporting, attorney-client visitation, and facilities inspection. ${ }^{5}$ In addition, the agreement contains attached exhibits that dictate the minimum standards for licensed programs with which the Service contracts for the temporary placement of juveniles in its custody, such as access to medical and mental health care, educational materials, recreational activities, religious observance, and legal services. ${ }^{6}$

The central guiding principal of Flores requires that the INS treat all minors with "dignity, respect and special concern for their particular vulnerability as minors." 7 To this end, it is incumbent on the Service to place children in the "least restrictive setting appropriate to the minor's age and special needs," 8 including releasing children to an appropriate caregiver or otherwise housing them in the least restrictive setting possible, such as one of eight shelters opened by the INS to house children in its custody. The majority of these shelters are institutional in nature and offer an environment of "soft detention": the children's activities and location are closely monitored; the doors are frequently locked or alarmed; and children are not allowed off the premises of the facility unless accompanied by facility staff. However, the children wear street clothing, are offered educational classes, and are not locked in cells. Occasionally, they engage in recreational or educational trips off-site with shelter staff. The INS also has an extremely limited foster care program, generally used for young children, girls, or children with special needs.

Because of the INS backlog of cases and a grossly inconsistent system for placement determinations among the thirty-three geographic INS districts, however, the advocate community has witnessed the pervasive exploitation of secure confinement that constitutes anything but the "least restrictive setting appropriate." The INS shelter and foster care program simply has failed to keep pace with the number of children in custody. ${ }^{9}$ Thus, as a result of the lack of bed space in the shelters and sometimes questionable placement decisions made by the INS, approximately one-third of children in INS custody spend time in a juvenile jail, for periods ranging from a few days to more than a year. ${ }^{10}$ Many of these children have not committed any crime at all. Despite this, they are housed in highly punitive, restrictive settings; are commingled with youthful offenders; are subject to handcuffing and shackling; and are forced to wear prison uniforms. Staff are ill-informed 
about the INS-detained children and remain unaware of their legal, cultural, and mental health needs. Educational programs typically are conducted only in English. Immigration lawyers who can assist the children often are unavailable, resulting in the questionable removal of children who actually might be eligible for immigration relief. On some unfortunate, but not entirely unusual, occasions, speculative age determinations even result in the placement of teenagers in highly inappropriate adult detention centers, where such children find themselves commingled with adult criminal offenders.

\section{Observations from the Field}

An eleven-year-old child is meeting with counsel to discuss her immigration or asylum case. The lawyer enters the room to find the child handcuffed, a practice the INS claims to be a security measure. The child is so small, however, that the handcuffs are "practically falling off his hands." The INS detains the child at the Berks County Youth Center in central Pennsylvania while the immigration proceedings progress. The meeting, on the other hand, is taking place at a courthouse about an hour away from the Center, so INS transports the child to appear before the immigration judge. While transporting the child, and during the child's appearance in court before an immigration judge, the handcuffs remain in use.

Advocates have documented many instances where the INS or its contracted facility has used restraints, including handcuffs and ankle shackles, in the facility and during the transportation of a minor to and from immigration court and proceedings. ${ }^{12}$ A minor at the Texas Liberty County Detention Center reported that he regularly was handcuffed and shackled by guards as a form of punishment. Children detained at Berks County Youth Center told Human Rights Watch that they had been handcuffed during transit to hearings, and some indicated that they had remained in restraints and cuffs for up to eight hours, including during time spent in consultation with an attorney. ${ }^{13}$

According to the Service, by its own determination and discretion it may restrain a child at any and all times when believing that there is a safety risk involving the child, even during meetings with lawyers. When asked about the use of restraints, the INS insisted that it is at the discretion of the officer whether or not the use the restraints during transportation is needed. The INS also responded to questions from Human Rights Watch stating that the use of restraints was within its rights because handcuffs are utilized as a security measure. ${ }^{14}$ Thus, many juveniles are placed in handcuffs and shackles when they are taken to court hearings or are forced to wear jail clothing. This practice not only disrespects the most basic human rights of these children, but often is psychologically and emotionally damaging and humiliating for chil- dren who already have experienced traumatic experiences of death, abandonment, harassment, and abuse by other adults.

Nicolas is a sixteen-year-old child who constantly was shuffled among facilities by the INS. Nicolas originally was in a shelter in Arizona, where he had been fortunate to obtain the services of pro bono counsel. However, the INS suddenly transferred Nicolas first to Los Angeles County, and then to Tulare County, a facility more than a three-hour drive from either Los Angeles or San Francisco. His transfer was in clear violation of the Flores $v$. Reno settlement, which states that "[n]o minor who is represented by counsel shall be transferred without advance notice to such counsel." ${ }^{15}$ The transfer and lack of communication thereafter with his lawyer left Nicolas depressed and suicidal.

Three Columbian children were given thirty minutes notice that they were departing from the Florida facility at which they had been detained for nearly a year and were to be relocated far from their pro bono counsel. Their attorney arrived at the facility the next day to discover that the children had been transferred more than a thousand miles away to Chicago, and that the day before the INS attorney had obtained a change of venue, without notice to the children's attorney, precluding any objection to the transfer.

Sudden transfer of children from facility to facility by the INS, even in the middle of the night, without warning to lawyers or to families or guardians, violates not only the terms of the Flores agreement and other INS regulations, but also generally accepted international standards for the treatment of children. ${ }^{16}$ Under the terms of the Flores settlement, a child represented by counsel cannot be transferred to any facility without prior notice to their attorney, with the only exception to this rule being in "unusual and compelling circumstances," 17 and even in this instance the INS must notify the attorney within twenty-four hours of the transfer. Similarly, international standards secure adequate protection to the child's legal representation by requiring notice to counsel prior to a transfer.

The transfer of a child to another facility interferes with the ability of counsel to interview their clients, prepare applications for asylum and other forms of relief, and provide adequate representation. According to Human Rights Watch, INS officials stated that children could be represented adequately by phone and that there was little to be concerned about from the separations from attorneys or families or guardians. ${ }^{18}$ Thus, by transferring children from facility to facility, the INS creates 
obstacles for immigrant children to obtaining the status or aid to which they are entitled. The consequences of the INS's actions "enables courts to bypass the rights of these children to legal remedies altogether."19

Pablo, a teenage boy, is taken into the custody of the INS after crossing the southern border. He has been a street child since the age of five and eligible to obtain relief as a victim of abuse, abandonment, or neglect under the provisions of the Special Immigrant Juvenile visa. Although Pablo has not committed nor even been accused of committing any criminal act, he is housed for more than five months in a punitive detention centre in clear violation of his protections under Flores. He attends classes, eats meals, and engages in recreational activities alongside adjudicated juvenile delinquents. Pablo's cellmate is a county delinquent in the custody of local officials on charges of assault with a deadly weapon and felony drug possession.

A child who is seeking respite from persecution, torment, death, and destruction, and who may have developmental or other disabilities upon arrival in the United States, may be placed in a secure detention facility and commingled with juvenile offenders who have committed murder, rape, theft, or drug trafficking. Although the Flores agreement says that a minor "should be placed in an INS or INS-contract facility that has separate accommodations for minors, or in a State or county juvenile detention facility that separates minors in INS custody from delinquent offenders," ${ }^{20}$ the observed reality is quite to the contrary. As a matter of general practice, the Service contracts with local secure confinement facilities-such as Martin Hall Juvenile Detention Center in Spokane, Washington, and San Diego Juvenile Hall in San Diego, California - that are incapable of providing the nonoffender segregation that is required under Flores.

Moreover, advocates confirm that at facilities like Berks County, Pennsylvania, or Liberty County, Texas, children in secure detention are not segregated from children in delinquency proceedings. Children in INS custody either share rooms or have extensive contact-during meals, classes, physical training, and unstructured time-with juvenile offenders. ${ }^{21}$ In 1999 , according to the INS nearly two thousand minors were placed in higher security jail-like facilities, even though 78 per cent were not charged with any offense or had not displayed any disruptive behavioural patterns. Some child advocates note that the use of more severe and punitive methods to control delinquent youth problems is "inappropriate for immigrant children who may not speak English and may have experienced severe family abuse or other violence or trauma." 22

\section{Proposed Legislative Relief}

In order to address many of the deficiencies in the current system of INS treatment of unaccompanied alien juveniles, bipartisan-sponsored legislation was introduced in the Senate and House of Representatives of the United States Congress to restructure the legal and physical custody arrangements for these vulnerable children. Entitled the Unaccompanied Alien Child Protection Act of 2001,23 this much-needed legislation would achieve a number of goals designed to break the inherent conflict of interest that leaves the Service with the dual functions of custodial care and law enforcement responsibilities.

Most critically, the legislation would shift the responsibility for the care and custody of unaccompanied alien children to an agency still within the Department of Justice, but with no direct interest in the outcome of a child's case-the Office of Children's Services (OCS $)^{24}$ - thereby enabling the INS to focus its efforts on the legitimate law enforcement objectives of securing removal or release for these children. In doing so, the OCS will streamline INS procedures by eliminating the inherent conflict of interest that currently leaves it with concurrent jurisdiction for both custodial care of unaccompanied alien children and immigration law enforcement responsibilities.

Furthermore, the legislation will require, whenever possible, family reunification or other appropriate placement for unaccompanied alien children. ${ }^{25}$ Such placement options will expand shelter care facilities and foster care programs in which children receive services appropriate for their age and circumstances, limiting the appalling situation where the Service assigns non-offender children to punitive secure facilities where alien children are commingled with juvenile offenders.

Additionally, the legislation will ensure adequate legal representation for unaccompanied alien children through pro bono legal services or, if necessary, through appointed counsel. ${ }^{26}$ In addition, the bill will develop a corps of child welfare professionals to act as guardians ad litem and to make recommendations - regarding custody, detention, release, and removal-based upon the best interests of each child. These issues are discussed at length below.

A further problem faced by some unaccompanied alien teenagers is an improper age assessment resulting from imprecise dental forensic or bone-scan evidence. The ramifications of such judgments are far-reaching-aliens proclaiming facially valid juvenile status instead are placed in adult confinement - without separate accommodations for children, and without the broad entitlement protections ensured by Flores. ${ }^{27}$ For this reason, the bill will establish an age-determination system that enables unaccompanied alien children to present various forms of evidence proving their age, including an appeal procedure for adverse findings. ${ }^{28}$ 
At the same time, as critical as understanding what this legislation will accomplish is the recognition of what will not be affected by the proposal. Most importantly, and contrary to the uninformed assertions of some critics of the bill, the implementation of these reforms will not in any manner expand any rights to substantive grants of asylum or other forms of immigration relief beyond the current scope of United States immigration law. The language merely speaks to procedural-not substantive - transformation of the laws and regulations guiding the treatment of unaccompanied juveniles detained in government custody. No avenues of immigration relief are created by the bill, and therefore there is no reason to believe that the legislation would somehow act as a magnet, encouraging parents to send their children to the United States in pursuit of immigration relief. Without an opportunity for family members to obtain derivative status, the bill will not lead to an increase in illegal immigration by unaccompanied alien children.

Furthermore, the establishment of the OCS will not remove any current jurisdictional responsibility from the United States Department of Justice (DOJ), which houses the INS. Rather, the bill merely shifts the care and custody functions within the DOJ from the INS Detention and Removal Branch to a separate office with direct reporting to the Attorney General. Thus, although the legal custody for these juveniles will remain within an office of DOJ, no longer will the INS have the opportunity to exploit the inherent powers of custodial decisions to the detriment of a child's well-being. Within the modified framework of the OCS, critical evaluations-including placement and transfer-will reside solely within a branch of the government lacking any vested interest in the ultimate resolution of a child's immigration relief.

In addition, the legislative language will not modify the jurisdiction of either the INS or the Executive Office for Immigration Review (EOIR) to adjudicate claims for immigration relief. In the American system of adjudicating immigration claims, EOIR, established in 1983, houses both the immigration judges and the Board of Immigration Appeals (BIA) and has exclusive jurisdiction over applications for asylum brought by any alien for whom an immigration proceeding for deportation or exclusion already has been initiated. Like the proposed OCS, EOIR is an independent arm of DOJ-separate and apart from the INS - in order to preserve the integrity of the adjudication function vis-à-vis the immigration enforcement function of INS. In addition to "defensive" applications for asylum EOIR judges decide a litany of immigration matters. Along the same lines, all affirmative claims for asylum relief (those brought voluntarily by aliens not in the midst of removal proceedings) still will be determined by the Service Asylum Officers of the INS.
Finally, under the scheme envisioned by the bill, custodial rights of a parent or guardian in situations where a parent or guardian seeks to establish custody, making family reunification possible, will remain of paramount concern to OCS. The proposal in no way will interfere with any efforts to secure placements for unaccompanied children in the homes of suitable adult sponsors-especially family members-while they await an adjudication of their immigration claims. In fact, among the fundamental stated purposes of the bill is to "establish a government policy in favour of family reunification whenever possible." 29

\section{Procedural Barriers to Children's Asylum Claims}

The U.S. asylum system traditionally has done little to accommodate the asylum claims of children. Typically, children's claims were subsumed under those of their parents and not considered separately. If the parent was granted asylum, then so too was the child. This approach, however, failed to take into account the fact that in some cases, the family may be actively participating in, or at least condoning, the abuses experienced by the child. Without separate consideration of the child's situation, such grounds for asylum were likely never to surface in the adjudication.

Alternatively, if a child is unaccompanied by a parent, their cases are handled in the same fashion as those of adults. This "one-size-fits-all” approach frequently fails to take into account the unique situation of a child, including her cognitive and emotional stage of development, and the impact that may have on the child's ability to recollect and articulate a traumatic experience in the home country. Such failure to consider the child's circumstances undermines the ability to gain asylum; a child cannot be expected to shed her childhood for purposes of a legal proceeding.

The INS addressed at least some of the barriers which confront children in the asylum process in December 1998. Working with non-governmental organizations, refugee and children's experts, and the United Nations High Commissioner for Refugees (UNHCR), the INS released "Guidelines for Children's Asylum Claims" (the "Guidelines"). ${ }^{30}$ By doing so, the United States became the second country in the world (the first was Canada $)^{31}$ to establish a framework for the consideration of children's asylum claims. The Guidelines are groundbreaking in their comprehensive establishment of legal, evidentiary, and procedural standards to guide adjudicators. 
The Guidelines highlight several key principles that should steer the adjudication of children's claims. First, the Guidelines acknowledge that the "best-interests-of-the-child" standard as a useful measure for ensuring that procedural protections are in place when adjudicating children's claims, although they also explicitly deem the best-interest rule as inapplicable to the substantive determination of a child's claim. Presumably, the INS was reluctant to inject a best-interests element into the analysis of a child's claim out of fear of widening too broadly the application of the refugee definition to children.

The Guidelines also open the door to allowing a "trusted adult" 32 to accompany a child to the asylum interview. The Guidelines indicate that the trusted adult will normally be a relative but may be some other adult who can offer support to the child through the interviewing process. This provision responded to a call by outside experts to appoint guardians ad litem to assist children through their proceedings. ${ }^{33}$ While the role of the trusted adult falls short of fulfilling the role of a guardian ad litem, it does at least acknowledge the importance of adult assistance in shepherding children through the asylum process. The Guidelines, however, also underscore the importance of a separate determination in children's cases when their parent is denied asylum.

The Guidelines are perhaps most significant in their practical recommendations on how adjudicators can establish a child-friendly interview environment through rapport-building activities and appropriate questioning and listening techniques. While many of these recommendations, such as avoiding "legalese" and the use of abstract concepts, may seem to be simple common sense, the Guidelines provide a useful compendium to ensure that adjudicators not lose sight of the child's special needs during the asylum interview. ${ }^{34}$

The Guidelines are limited in two important ways. First, they are non-binding. Second, they were designed primarily for use by INS asylum officers, who are responsible for the initial non-adversarial adjudication of asylum claims presented by individuals in lawful status in the United States and/or who present themselves to the INS and request asylum after already having entered the country. The Guidelines have not been formally adopted by EOIR, including the immigration court judges and the BIA, the two departments that oversee all deportation proceedings in the United States. Despite not having formally adopted the Guidelines, however, EOIR has trained its immigration judges and board members under the Guidelines.

Despite the limitations of the Guidelines, a number of children have been granted asylum based on unique claims since their issuance. For example, Central American street children, Indian child labourers, and young Chinese girls forced into marriage have won their cases. Fundamental to the consideration of these cases has been an increasing acknowledgement that children may experience persecution differently than adults.

However, the U.S. asylum system continues to deny children two critical sources of help: the guarantee of counsel and the appointment of guardians ad litem. Asylum proceedings are extraordinarily complex and a recent study revealed that represented asylum seekers are four to six times more likely to win their asylum cases. ${ }^{35}$ The ability of children who remain unrepresented to win their cases is even more questionable given their inherent lack of capacity to understand the proceedings in which they have been placed. Despite this, in contrast to many other western asylum countries, U.S. asylum law fails to ensure counsel to asylum seekers. Under the INA, non-citizens have the right to counsel in immigration court proceedings but at no expense to the government. ${ }^{36}$ Federal courts have deemed this right to be fundamental to the adjudication of asylum cases. ${ }^{37}$

The practical reality for most asylum seekers is that they cannot afford or cannot access attorneys if detained. This is even more true for children, who may not even be aware of the importance of counsel to their cases. In addition, the sheer number of detention facilities in which children in INS custody are detained combined with the remote location of many of these facilities creates innumerable obstacles which charitable legal services organizations lack the resources to overcome. As a result, less than half of INS-detained children have legal representation. The lack of legal representation results in sometimes ludicrous situations; in one case, for example, an eighteen-month-old toddler appeared at a preliminary hearing with no attorney or other adult representative.

Also out of step with the practice of other countries, as well as the practice in other areas of U.S. law such as abuse and neglect proceedings, is the fact that unaccompanied children seeking asylum are also not appointed guardians ad litem. Guardians could usefully function in loco parentis in the context of a court proceeding to encourage children to participate to the fullest extent possible and appropriate and to help ensure that decisions reached on behalf of children during proceedings comport with the principle of the best interests of the child.

The guardian ad litem will work directly and closely with the child to:

- ascertain the child's views;

- help the child articulate his or her story;

- offer independent advice to the child; 
- help develop the child's awareness of the options that are open to him or her and elicit the child's preferences about these options;

- act in loco parentis during the immigration proceedings to encourage the child to participate to the fullest extent possible and appropriate and to help ensure that the decisions reached on behalf of the child during the proceedings comport with the child's best interests; and

- help the asylum officer or immigration court to reach a decision in the case that is appropriate to the child's circumstances, keeping in mind that such decisions must also comport to the requirements of U.S. immigration and asylum law.

Ideally, child welfare professionals would function as guardians ad litem. It is critical that the role of the guardian ad litem be distinct and separate from that of the child's attorney, who is charged with representing the child in immigration court and seeking relief that is in keeping with the child's expressed interests. However, in order to ensure that the best interests of the child are addressed, to the maximum extent possible, the guardian must work closely with the child's attorney. Through such collaboration, the chances that a decision is reached in the child's proceedings that is truly in keeping with the child's interests will be maximized. Moreover, it is likely that effective participation of the guardian in the court proceedings will render such proceedings more efficient and therefore lead to a faster resolution of the child's case.

The need for government-funded counsel and guardians ad litem has been recognized by EOIR. It is a concept that has also been embraced by key members of the U.S. Congress, who have introduced legislation that would provide such assistance to children as well as transfer custody of the children away from the INS to a new Office of Children's Services. ${ }^{38}$

\section{Conclusion and Recommendations}

U.S. policy must be based on the recognition that unaccompanied children who arrive in the United States in search of refugee protection are children first and have a fundamental right to due process and care that is appropriate to their young age. It must also recognize that each child's case is unique and must inform the outcome of their asylum proceedings.

To reach these goals, the U.S. government must redress the inherent conflict of interest in the INS's handling of children and implement measures to address a child's lack of capacity to navigate asylum proceedings alone. To that end, the U.S. should take the following steps:

- require expanded shelter-care facilities and foster-care programs in which children would receive culturally and ageappropriate services;

- provide government-funded counsel to children;

- mandate the development of a corps of professional guardians ad litem to assist in meeting the best interests of each child;
- establish an age-determination system that allows a child to present a variety of forms of evidence to prove his or her age and incorporates an appeal process for adverse age findings; and

- eliminate the conflict of interest experienced by the INS by moving jurisdiction over the care of children asylum seekers to an agency with child welfare expertise and no interest in the outcome of the child's immigration or asylum proceedings. Presently, the INS is charged with providing care to the same children that it is concurrently trying to deport.

The U.S. has a proud history in recognizing the rights of both children and refugees. It now is time to apply these standards in the context of the U.S. asylum system.

\section{Notes}

1. United States Immigration and Naturalization Service, $J u$ venile Detention and Shelter Care Program, 9/2000, available at $<$ www.ins.gov $>$.

2. Immigration and Nationality Act, 8 U.S.C. $\$ 101$ (2001).

3. Id. $\$ \$ 101(\mathrm{~b})-(\mathrm{c})$.

4. See Stipulated Settlement Agreement, Flores v. Reno, Case No. CV 85-4544-RJK (C.D. Cal. 1996), available at $<$ www.centerforhumanrights.org/FloresSettle.html> [hereinafter Flores].

5. See id. $9912,25,28 \mathrm{~A}, 32,33$.

6. See id. at Exhibit 1.

7. Id. 911.

8. Id.

9. See Letter from Center for Human Rights and Constitutional Law, Flores Counsel to Plaintiff's Class, to INS Director of Policy Directives and Instruction (Sept. 16, 1998) (on file with author).

10. See Letter from Center for Human Rights and Constitutional Law, Flores Counsel to Plaintiff's Class, to Arthur Strathern, INS Counsel, and John Pogash, INS Deputy Director of Juvenile Affairs (Sept. 16, 1998) (on file with author).

11. Detained and Deprived of Rights: Children in the Custody of the U.S. Immigration and Naturalization Service, Human Rights Watch at 6, December 1998, available at $<$ www.hrw. org/reports98>.

12. See Gregory Zhong Tian Chen, Elian or Alien? The Contradictions of Protecting Undocumented Children Under the Special Immigrant Juvenile Statute, 22 Hastings Const. L.Q. 597, 619-22 (2000).

13. See Detained and Deprived of Rights, supra note 11, at 6 .

14. See id.

15. Flores v. Reno, 507 U.S. 292, 295 (1993).

16. See Detained and Deprived of Rights, supra note 11, at 8.

17. Flores, supra note $4,927$.

18. See Detained and Deprived of Rights, supra note 11, at 8 . 
19. Sharon Finkel, Voice of Justice: Promoting Fairness Through Appointed Counsel for Immigrant Children, 19 N.Y.L. Sch. J. Hum. Rts. 1105, 1115-16 (2001).

20. Flores, supra note $4, \mathbf{g} 17$.

21. See Detained and Deprived of Rights, supra note 11, at 10.

22. Chen, supra note 12, at 619.

23. The Unaccompanied Alien Child Protection Act of 2001, S. 121, $107^{\text {th }}$ Cong. (2001); The Unaccompanied Alien Child Protection Act of 2001, H.R. 1904, 107 ${ }^{\text {th }}$ Cong. (2001) [hereinafter Child Protection Act].

24. See id. $\$ 101$.

25. See id. $\$ 202$.

26. See id. $\$ 302$.

27. See Flores, supra note 4, 12.

28. See Child Protection Act, supra note 23, $\$ 205$.

29. Flores, supra note 4, 14; see also Child Protection Act, supra note $23, \S 202$.

30. United States Immigration and Naturalization Service, Guidelines for Children's Asylum Claims (Dec. 10, 1998) [hereinafter Guidelines].

31. See, e.g., Jacquie Miller, Canada First to Adopt Guidelines for Child Refugee Claimants, Ottawa Citizen, Aug. 27, 1996.

32. Guidelines, supra note 30 , at 5 .

33. Id. at 6.

34. Id.

35. See, e.g., Memorandum from Andrew Schoenholtz, Georgetown University Institute for the Study of International Migration (Sept. 12, 2000) (on file with author).

36. See Immigration and Nationality Act, 8 U.S.C. $\$ 240$ (b)(4) (2001).

37. See Orantes-Hernandez v. Thornburgh, 919 F.2d 549, $554\left(9^{\text {th }}\right.$ Cir. 1990).

38. See Child Protection Act, supra note 23.

Andrew Morton serves as a government relations associate with the law firm of Latham and Watkins in Washinton, D.C. He has acted as pro bono counsel to the Women's Commission for Refugee Women and Children in its effort to seek legislative reform of U.S. treatment of children in asylum proceedings.

Wendy Young is the director of government relations and U.S. programs for the Women's Commission for Refugee Women and Children in Washington, D.C. In that capacity, she directs the Commission's Detention and Asylum Project, and has assessed the treatment received by women and children asylum seekers in the United States.

(C) Andrew Morton and Wendy A. Young, 2002. This open-access work is licensed under a Creative Commons Attribution-NonCommercial 4.0 International License, which permits use, reproduction and distribution in any medium for non-commercial purposes, provided the original author(s) are credited and the original publication in Refuge: Canada's Journal on Refugees is cited. 